\title{
Article \\ Structure and conditions for the functioning of the polish-czech cross-border market of cultural services
}

\author{
Łukasz Wróblewski 1,* \\ 1 Department of Management and Production Engineering, WSB University, 41-300 Dąbrowa Górnicza, Poland \\ * Correspondence: lwroblewski@wsb.edu.pl; Tel.: +48-692-344-057
}

\begin{abstract}
This is a theoretical and empirical article. In the first part, an original definition of the cross-border market for cultural services has been developed, based on classic market definitions. The structure and conditions of functioning for this market have also been presented. The next part of the article discusses the supply side of the cross-border market of cultural services for the two twin towns: Cieszyn (Poland) and Český Těšn (Czech Republic). Next, based on the surveys conducted, the participation of residents of both towns in the most important cultural events organised by cultural institutions on both sides of the border was examined.
\end{abstract}

Keywords: Cieszyn - Český Těšín, participation in culture, consumer behaviour, cross-border cooperation, market for cultural services.

\section{Introduction}

The Polish-Czech border region, despite the fact that it is very diverse in many respects, simultaneously belongs to the most durable European spatial structures. The community that lives on both the Polish and Czech side is predominantly homogeneous, although a German population can also be found on the section of the Polish-Czech border running through the Opole and partly Silesian provinces. The western part of the Polish-Czech border counties is often inhabited by Poles displaced to this area after the Second World War. It can be said that this part of the Polish-Czech border region has the character of a new borderland, where new local communities often meet, which due to their inhomogeneous population have not yet developed strong cross-border links (Wróblewski 2016).

However, the situation is quite different in the eastern part of the Polish-Czech borderland, especially in Cieszyn Silesia, which is located around the towns of Cieszyn and Český Těšn. This area is geographically different, because the border does not run through the mountains (Beskidy, Sudety) in this region, but in an area that is easily accessible - the valleys of Odra and Olza rivers. Moreover, the population of the border areas has been rooted there for a long time, and additionally, on the Czech side, there is a Polish minority centred around the Polish Cultural and Educational Association in the Czech Republic (Kurowska-Pysz 2016, Wróblewski 2015). This means that many people on both sides of the border are closely or distantly related, and even own land on the opposite side of the border. Such an area encourages close Polish-Czech cross-border cooperation. It encourages cooperation in the field of culture and the implementation of joint activities within the cross-border market for cultural services.

\section{The concept of a cross-border market for cultural services}

The market is a concept widely used both among theoreticians and practitioners, very often interpreted in an arbitrary manner - depending on the purpose of formulating the concept of a market, often very simplified (Kędzior 2005, p. 9). This concept was already known in ancient times, when the purchase and sale transactions took place in specially designated places (e.g. the Greek Agora, the Roman Forum), hence the market was originally defined as a place of exchange, as the central square of a city (Chotkowski 2013, p. 54). With time, it started to be considered more widely in geographical terms - as an area with similar purchase and sale conditions (e.g. the Polish-Czech 
borderland or the area of the Euroregion Śląsk Cieszyński). Over the years, however, it was noted that this approach to the market expresses a very narrow definition of the technical (historical) and geographical definition of the market, which is why its subsequent definitions appeared. And so, in cybernetic terms, the market is a deliberately organised system of relations between subjective and objective elements of the market, in which real and regulatory processes occur (Kędzior 2005, p. 9). Through the continuous process of buying and selling, market participants go from the relative ignorance of the desires and needs of others to a fairly accurate understanding of how much can be bought and sold and at what price (Kamerschen et al. 1992, p. 47). The market as an economic category is the sum of trading relations (commodity and money) between sellers offering products at a specified price and representing the supply, and buyers reporting the demand for these products covered by purchasing funds and representing the demand (Mynarski 2000, p. 7). Thus, the market is the relation of three elements: supply, demand and price, which is shaped as a result of the meeting of supply and demand. In other words, it is a confrontation of the supply and demand for a given good which affects the price of the goods and the volume of exchange (Bremond et al. 2005, p. 197). Market specialists define the market in yet another way. In marketing, the market is considered in a much narrower sense than in the economic sense. It has been assumed that in the market economy there is the advantage of supply over demand, and the main problem for enterprises (including cultural institutions) is the shortage of demand for manufactured products. Therefore, instead of the three elements of the market (demand, supply and price), only the demand side is included in the marketing sense. The market is thus defined as buyers, and the sellers are treated as a sector (Kotler 2004, p. 173).

In attempting to define the cross-border market for cultural services, both the economic and geographical market definition were used, according to which the cross-border market for cultural services is the whole of the exchange relations between service providers that meet cultural needs and the consumers purchasing these services in the regions of the countries sharing a common border (Wróblewski et al. 2018a). In other words, it will be a collection of buyers (consumers of culture services) and sellers (cultural institutions and cultural industries) who carry out transactions regarding cultural services in areas along the border of the countries (border and cross-border regions). A geographical understanding of the cross-border market for cultural services indicates a territory which is located on both sides of the border, as a separate area with similar purchasing and selling conditions. The classic (economic) understanding of the market reduces the definition of the cross-border market for culture services to the general exchange relations between sellers, offering services that meet cultural needs and buyers - representing a demand for these services. It includes both the subjective (who participate in the trading process) and the objective aspect (which is the object of trade) - Figure 1. 


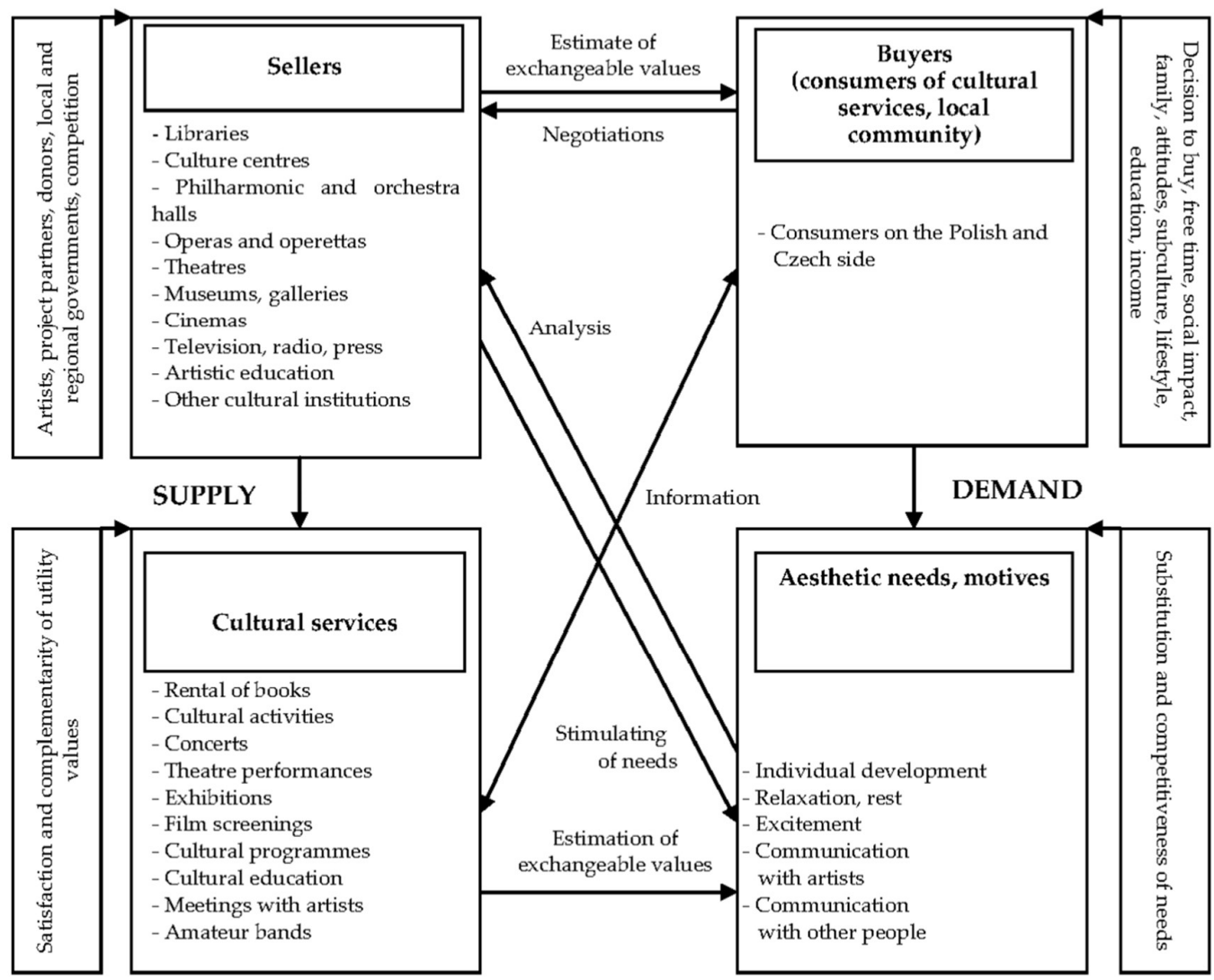

Figure 1 Structure of the cross-border market for cultural services Source: Own work.

The cross-border market for cultural services should therefore be treated as a system whose elements form a specific structure. In this system, we can distinguish (Kędzior 2005, p. 10):

- Market entities - i.e. the sellers (cultural institutions, organisations, companies in cultural industries) and the buyers (consumers of cultural services);

- Market objects, i.e. cultural services and aesthetic needs, motives for using the services of cultural entities available on the market);

- Relations between market entities and objects.

Market conditions for the functioning of the Polish-Czech cross-border market for cultural services are presented in Figure 2.

Art market - creators of culture PL
Market for the dissemination of culture

PL

$\mathrm{CZ}$
Art market - creators of culture $\mathrm{CZ}$ 


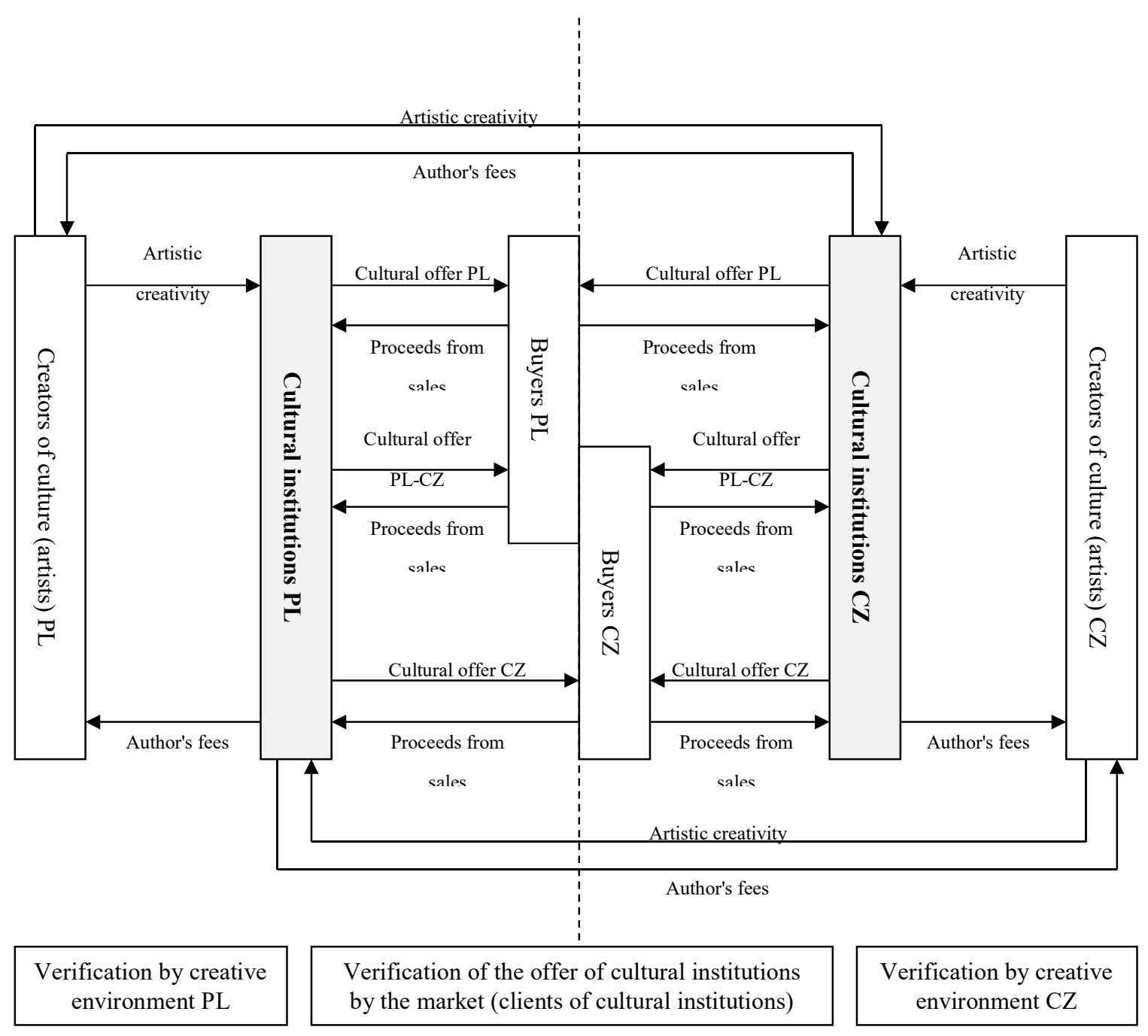

Figure 2 Conditions for the functioning of the Polish-Czech cross-border market for cultural services Source: Own work.

As shown in Figure 2, two separate markets can be distinguished from the Polish-Czech crossborder market for cultural services:

- Art market - market of the creators of culture,

- Market for the dissemination of culture.

On the supply side of the cross-border art market, there are creators of culture, in the widest sense of the concept, both in Poland and in the Czech Republic. These are not only individual creators, but also institutions for creating culture (institutions creating musical, visual, literature and multimedia works). The works of art, produced by the creators, are subjected to verification by the environment of critics, art experts and other artists in the given country (Poland, Czech Republic) (Wróblewski 2017a, 2017b). When verification is successful, in accordance with the institutional definition of art by G. Dickie (1984, p. 80) and A.C. Danto (1964, pp. 571-584), the creator's work is given the status of a candidate for artistic evaluation. This evaluation through the institution of dissemination of culture is carried out on the Polish-Czech cross-border market for the dissemination of culture by Polish and Czech buyers (consumers of culture services). If the cultural institution's offer meets with the approval of its clients, the creator's work goes into general circulation on the Polish-Czech cross-border market for cultural services. In return for the cultural offer, the buyers provide the cultural institutions with funds, which then go to the creators. In relation to the cross- 
border market for cultural services, it is also important that the creator of culture can evaluate their work both by means of national cultural institutions and those located on the other side of the border.

\section{Cieszyn - Český Těšín as an example of the cross-border market for cultural services}

Cieszyn, with approximately 36,000 residents and Český Těšín (approximately 25,000 residents) are the main towns in the Cieszyn Silesia region and the Euroregion Śląsk Cieszyński located on the River Olza. This region lies in the border area of southern Poland and north-eastern Czech Republic, in the close vicinity of Slovakia. Originally, Cieszyn Silesia belonged to the Great Moravian Empire (Wróblewski et al. 2018b). Before 991, it became a part of the Polish state, and at the turn of 1289 obtained the status of a separate Duchy of Cieszyn which became part of the Czech crown in 1327. After the Piast dynasty ceased to exist in 1653, the Duchy became the property of the Habsburg family. For a century and a half, the entire area belonged to one state, the Austro-Hungarian Empire. This condition lasted until its dissolution in 1918. At that time, there was a conflict over this territory which, on July 28, 1920, by the decision of the Council of Ambassadors of the Great Powers at the conference in SPA, was divided between the newly reborn Poland and the newly formed Czechoslovakia. Artificially dividing the historically, ethnographically and socially homogeneous area (including the town of Cieszyn into Cieszyn and Český Těšín) became the cause of mutual Polish-Czech animosities, grievances and conflicts that blocked the creation of the Polish-Czech crossborder market for cultural services for many years (Werpachowski 2014, pp. 15-25, Wróblewski 2016, pp. 50-52).

Cieszyn and Český Těšín (Czech Cieszyn) are special not only because of their history, unique location and terrain, but they are also famous for numerous cultural entities and many exceptional cultural events, some of which, as shown by research conducted in 2014, are known and appreciated both in Poland and the Czech Republic (Wróblewski 2014a, pp. 68-72).

Table 1 lists the Cieszyn cultural entities that make up the supply side of this specific crossborder market.

Table 1. Cultural institutions and entities of the Cieszyn cultural industries.

\begin{tabular}{|c|c|}
\hline $\begin{array}{l}\text { Cultural institutions in } \\
\text { Cieszyn }\end{array}$ & $\begin{array}{l}\text { Entities in cultural industries in } \\
\text { Cieszyn }\end{array}$ \\
\hline Theatres & Audiovisual and film industry \\
\hline Adam Mickiewicz Theatre in Cieszyn & "Piast" cinema in Cieszyn, Kultura na Granicy \\
\hline Museums & Association , Cieszyn Film Festival \\
\hline Museum of Cieszyn Silesia, Museum of Printing, Museum of & "Wakacyjne Kadry" organised by the Town of \\
\hline Protestantism, Museum of the 4th Regiment of Podhale Rifles. & Cieszyn \\
\hline Libraries & Publishing and press industry \\
\hline Cieszyn Library, Municipal Public Library in Cieszyn, Museum and & Głos Ziemi Cieszyńskiej, haloCieszyn.pl, \\
\hline Library of the Brothers Hospitallers & Drukarnia Wydawnictwa ARKA, Oficyna \\
\hline Culture centres & Drukarsko-Wydawnicza "AKANT" s.c., \\
\hline Cieszyn Cultural Centre, Cieszyn Castle, Neighbourhood Cultural and & Wydawnictwo \& drukarnia Logos Press, \\
\hline Recreation Centre & Dom Wydawniczy LONGPRESS, \\
\hline Galleries & Przedsiębiorstwo Poligraficzne MODENA, \\
\hline UL Kultury in Cieszyn, w Bramie Gallery & INTERFON Wydawnictwo - drukarnia. \\
\hline Cultural and educational organisations & \\
\hline Macierz Ziemi Cieszyńskiej, "Na Granicy" Politcal Critique Centre & \\
\hline Music bands, choirs, orchestras & \\
\hline $\begin{array}{l}\text { Harmonia Silesian University Choir, Janina Marcinkowska Song and } \\
\text { Dance Ensemble of the Cieszyn Region, "Cieszynianka" Brass Band. }\end{array}$ & \\
\hline
\end{tabular}

A large number of cultural entities active in Cieszyn means that there is aa rich and diverse cultural offer. According to the data of the Cultural Department of the Cieszyn Town Hall in 2016, more than 1,600 cultural events were organised by local government cultural institutions in which more than 265,000 people participated (as estimated by the organisers of these events). 
The supply side of the cross-border market for cultural services also includes numerous cultural entities in Český Těšín (Table 2).

Table 2. Cultural institutions and entities of the Český Těšín cultural industries.

\begin{tabular}{|c|c|}
\hline $\begin{array}{l}\text { Cultural institutions } \\
\text { in Český Těšín }\end{array}$ & $\begin{array}{c}\text { Entities in cultural industries } \\
\text { in Český Těšín }\end{array}$ \\
\hline $\begin{array}{l}\text { Theatres } \\
\text { Těšín Theater in Český Těśn } \\
\text { Museums } \\
\text { Museum of the Těšín Region } \\
\text { Libraries } \\
\text { Municipal Library in Český Těšín } \\
\text { Culture centres } \\
\text { Youth Centre in Český Těšín, KaSS Strelnice } \\
\text { Cultural and educational organisations } \\
\text { Polish Cultural and Educational Association in the Czech Republic, Association } \\
\text { of Polish Book Friends, Polish Society of Singers Collegium Canticorum, Polish } \\
\text { Art Society "Ars Musica", Macierz Szkolna w Republice Czeskiej, Pedagogical } \\
\text { Centre for Polish National Education Cafe AVION } \\
\text { Music bands, choirs, orchestras } \\
\text { Representative Group of the Central Board of the Polish Cultural and Educational } \\
\text { Association "OLZA", "Slezan" folk ensemble from Český Těšín }\end{array}$ & $\begin{array}{l}\text { Audiovisual and film industry } \\
\text { "Central" Cinema in Český Těšín, } \\
\text { Education Talent Culture } \\
\text { Association - organisers of "Cinema } \\
\text { on the Border" Film Review } \\
\text { Publishing and press industry } \\
\text { Voice, PZKO ZWROT monthly, } \\
\text { FINIDR, s.r.o. in Český Těšín }\end{array}$ \\
\hline
\end{tabular}

The data contained in the reports of the local government cultural institutions in Český Těšín show that in 2016 about 140,000 people participated in cultural events organised by Czech cultural institutions.

The rich cultural offer of Cieszyn and Český Těšín, which is the result of the activities of numerous entities on the cross-border market for cultural services, is addressed, in large, to both residents on the Polish and Czech side of the border. However, the cross-border market for cultural services consists not only of the supply side entities of the market, but also the buyers (consumers of culture) which create its demand side. Therefore, it is worth taking a closer look at the participation of the inhabitants of both towns in cultural events which are organised.

\section{Residents of Cieszyn and Český Těšín as participants in the cross-border market for cultural services}

Primary research for the purposes of this article was conducted on a group of 799 inhabitants of Cieszyn and Český Těšín (which constitutes about 1.3\% of the total population of these towns) who, in 2017, participated at least once in a cultural event organised in one of the twin towns. The research was carried out using a survey, with the use of the PAPI (Paper and Pen Personal Interview) and the CAWI (Computer Assisted Web Interview). Basic information about the research conducted is presented in Table 3.

Table 3. Basic information about the research.

\begin{tabular}{|l|ll}
\hline Specification & Research
\end{tabular}




\begin{tabular}{|c|c|}
\hline Research method & Survey \\
\hline Research technique & $\begin{array}{l}\text { PAPI (Paper and Pen Personal Interview) } \\
\text { CAWI (Computer Assisted Web Interview) }\end{array}$ \\
\hline Research tool & $\begin{array}{c}\text { Paper questionnaire } \\
\text { Electronic questionnaire } \\
\end{array}$ \\
\hline Sample selection & $\begin{array}{c}\text { Targeted (non-random) } \\
\text { (residents of Cieszyn and Český Těšín taking advantage of the cultural offer of these } \\
\text { towns) }\end{array}$ \\
\hline Sample size & 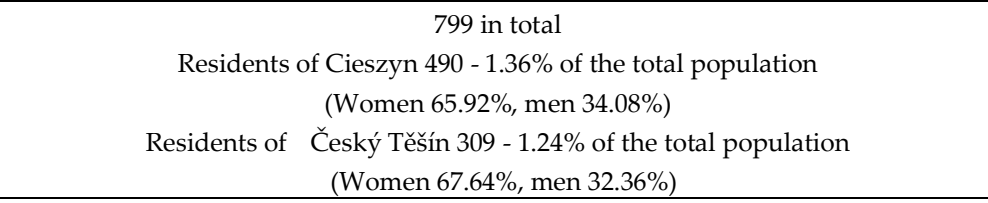 \\
\hline Spatial extent of research & Cieszyn and Český Těšín \\
\hline Research date & October 2017 - January 2018 \\
\hline
\end{tabular}

The research was part of the project entitled "Programme for the Culture of Cieszyn and Český Těśín" co-financed by the European Regional Development Fund - Interreg V-A Programme Czech Republic-Poland as part of the Micro-Projects Fund of the Euroregion Śląsk Cieszyński - Těšínské Slezsko and the state budget.

One of the main issues examined was related to the frequency of using the cultural offer. The residents of Cieszyn and Český Těšín were asked about how often they took advantage of the cultural offer of institutions and cultural entities located in Cieszyn (on the Polish side) and Český Těśín. The summary results with the division into residents of Cieszyn and Český Těšín are presented in Table 4 .

Table 4. Frequency of taking advantage of the offer of cultural institutions and entities in Cieszyn and Český Těšín in 2017 by residents [in \%].

\begin{tabular}{|lc|c|c|c|c|c|c|c|c|}
\hline \multirow{2}{*}{ Specification } & \multicolumn{4}{|c|}{ Residents of Cieszyn } & \multicolumn{5}{c|}{ Residents of Český Těšín } \\
\cline { 2 - 10 } & & $\begin{array}{c}\text { Not } \\
\text { once }\end{array}$ & $\begin{array}{c}\text { Once or } \\
\text { twice }\end{array}$ & $\begin{array}{c}\text { A few } \\
\text { times }\end{array}$ & Many times & $\begin{array}{c}\text { Not } \\
\text { once }\end{array}$ & $\begin{array}{c}\text { Once or } \\
\text { twice }\end{array}$ & $\begin{array}{c}\text { A few } \\
\text { times }\end{array}$ & Many times \\
\hline $\begin{array}{l}\text { Cultural institutions } \\
\text { Cieszyn }\end{array}$ & in & 69.27 & 17.58 & 6.48 & 6.67 & 84.16 & 10.81 & 2.84 & 2.19 \\
\hline $\begin{array}{l}\text { Cultural institutions in } \\
\text { Ceský Těšín }\end{array}$ & & & & & & & & & \\
\hline
\end{tabular}

The data presented in Table 4 shows that the vast majority of Cieszyn residents has not taken advantage of the offer of a significant part of the cultural institutions located in their city. The cultural institutions that were visited by Polish respondents in 2017 usually included the Municipal Library in Cieszyn - 20.61\% of respondents, the Cieszyn Castle (17.14\%) - here, however, in the course of further in-depth research, it turned out that the respondents first of all had in mind a walk around the Castle Hill, not a visit to, for example, one of the Cieszyn Castle exhibitions, as well as the "Piast" Cinema (17.14\%). The situation is even less optimistic regarding the inhabitants of Český Těšín. The inhabitants of Český Těšín who took part in the survey most often visit such cultural institutions on the Polish side as: Cieszyn Castle (11.00\%) - similarly as in the case of Poles, visiting the Cieszyn Castle was most often in the form of a walk around the Castle Hill, "Piast" Cinema (4.53\%) and the Municipal Library in Cieszyn (3.24\%), which Poles living in the Czech Republic (members of the Polish Cultural and Educational Association in the Czech Republic) take advantage of most often.

The presented data also show that Poles living in Cieszyn very rarely visit cultural institutions that are located on the other side of the border. The Těśn Theatre is the cultural institution in Český Těšín, which enjoys the greatest interest among Poles. Nearly $5 \%$ of the surveyed residents of Cieszyn visited this institution in 2017 many times, 4.69\% of the Cieszyn residents surveyed visited the Těśn Theatre a few times and $12.45 \%$ of the them did so once or twice. Such a result could have been expected given the fact that the Theatre located in Český Těśín Cieszyn, in addition to the Czech theater group, features a "Polish Stage" - a group of Polish actors putting on plays in Polish. The 
respondents, residents of Český Těšín declared in turn that they most often take advantage of the offer of the literary café AVION, which is located in the immediate vicinity of the "Friendship Bridge" connecting Cieszyn with Český Těšín. In 2017, Café AVION was visited many times by $22.33 \%$ of the surveyed Český Těšín residents. In addition, the Municipal Library in Český Těšín was visited many times by $20.71 \%$ of respondents, and the Těšín Theatre - by $20.06 \%$ of the surveyed residents of Český Těšín.

\section{Conclusions}

Cooperation in the field of culture between Cieszyn and Český Těšín is one of the basic forms of cross-border activity aimed at "blurring the borderline" on this section of the Polish-Czech border. Its aim is to strive to strengthen the harmonious development of both twin towns and the cohesion of the entire Cieszyn Silesia region. Joint projects of Polish and Czech cultural institutions with an impact on the cross-border dimension can play an important role in this cooperation. However, the results of the conducted research show that over $84 \%$ of the surveyed residents of Český Těšín have not taken advantage of the cultural offer that is available on the Polish side of the border. It can be assumed, therefore, that the range of impact of Polish cultural institutions located in Cieszyn is limited mainly to the Polish side of the borderland. Similarly, the spatial range of impact of cultural institutions operating in Český Těšín is usually limited to the Czech side of the town. The research shows that $88.66 \%$ of the surveyed residents of Cieszyn have never taken advantage of the cultural offer available in Český Těšín.

Summing up, the research shows that despite the implementation of many cross-border cultural projects in Cieszyn and Český Těśín aimed at bringing the Cieszyn and Czech Cieszyn inhabitants closer together, there is still a very clear division into Poles and Czechs (Rusek and Kasperek 2012, pp. 97-129), and the Polish-Czech cross-border market for cultural services is at an early stage of development. This was also confirmed by the in-depth interviews conducted in 2018 by the authors with 40 experts from Cieszyn and Český Těšín (directors of all local cultural institutions, creators of culture, employees of cultural institutions, heads of culture departments and organisers of the most important cross-border events in Cieszyn and Český Těšín). The experts pointed to the main barriers that hinder the development of the Polish-Czech cross-border market for cultural services, such as:

- A low position of culture in the hierarchy of the needs of residents of both Cieszyn and Český Těšín,

- A lack of interest of the inhabitants of both towns in the culture of the neighbouring country,

- Difficulties in developing a cultural offer equally appealing to Poles and Czechs (even a very popular theatre actor in Poland may be completely anonymous to the residents of Český Těšín),

- Language barrier - ignorance or poor knowledge of the neighbouring country's language is an important barrier in the full receipt of the offer of some of the neighbour's cultural institutions (e.g. theatre, cinema or library),

- Economic barrier - for example, for the inhabitants of Český Těšín, the cultural offer of some Polish cultural institutions (e.g. the Adam Mickiewicz Theatre in Cieszyn) is less attractive price-wise than a similar cultural offer available in the Czech Republic,

- Psychological barrier - in the consciousness of some residents of Cieszyn and Český Těšín, there is a permanent border dividing the town into two different parts (Polish and Czech).

Despite the existing barriers, however, taking into account the large number, high quality and dynamics of Polish-Czech cross-border contacts in the field of culture (Kasperek 2014), it can be assumed that in the future this market will continue to develop, which is supported by, among others:

- The important position of culture in the strategic documents of both towns, the Cieszyn county, the Euroregion Śląsk Cieszyński and the provinces on both sides of the border (Kurowska-Pysz et al. 2017),

- A large number of various types of entities: public, commercial, non-governmental, dealing with culture on both sides of the border (Wróblewski 2014a, pp. 62-66),

- Great importance of culture as an element working on other areas important in the socioeconomic development of the whole region (e.g. tourism) (Howaniec and Kurowska-Pysz 2014, pp. 66-74, Szomburg 2002, pp. 9-12), 
The multiplicity and relative durability of bilateral partnerships based on cross-border projects in the field of culture, including, in particular, projects co-financed by the European Union, which foster the strengthening of cross-border cooperation (Kurowska-Pysz 2014, p. 18, Wróblewski 2014b).

\section{References}

1. Bremond, Janine, Couet Jean Francois, Salort Marie Martine. 2005. Kompendium wiedzy o ekonomii. Warsaw: Wydawnictwo Naukowe PWN. ISBN 978-83-01-14713-6

2. Chotkowski, Jacek. 2013. Rynek jako podstawowa instytucja gospodarki - pojęcie, struktury, efektywność. „Zeszyty Naukowe SGGW w Warszawie” Nr 101/2013.

3. Danto, Arthur Coleman. 1964. The Artworld. In: Aesthetics: The Big Questions. Edited by Carolyn Korsmeijer. Oxford: Blackwell Publishing.

4. Dickie, George. 1984. The Art Circle: A Theory of Art. New York: Haven.

5. Howaniec, Honorata, Kurowska-Pysz Joanna. 2014. Klaster jako instrument rozwoju polsko-słowackiej wspótpracy transgranicznej. Dąbrowa Górnicza: Wydawnictwo Naukowe Wyższej Szkoły Biznesu w Dąbrowie Górniczej.

6. Kamerschen, Dawid, McKenzie Richard, Nardinelli Clark. 1992. Ekonomia. Gdańsk: Fundacja Gospodarcza NSZZ Solidarność.

7. Kasperek, Andrzej (Ed.). 2014. Euroregion Ślask Cieszyński - Těšinské Slezsko. Wspótpraca transgraniczna i międzyregionalna prowadzona w obszarze trójstyku polsko-czesko-słowackiego. Cieszyn-Katowice: Polska Akademia Nauk Oddział w Katowicach-Stowarzyszenie Rozwoju i Współpracy Regionalnej „Olza”. ISBN 978-83-60071-77-9

8. Kędzior, Zofia (Ed.). 2005. Badania rynku, metody, zastosowania. Warsaw: PWE. ISBN 83-208-1547-9

9. Kotler, Philip. 2004. Marketing od A do Z. Warsaw: PWE.

10. Kurowska-Pysz, Joanna. 2014. Transgraniczny klaster kulturalny - uwarunkowania działalności, wnioski z badań. In: Perspektywy rozwoju sektora kultury w Euroregionie Ślask Cieszyński. Edited by Joanna Kurowska-Pysz, Joanna Łodziana-Grabowska, Zdenek Mikolas, Łukasz Wróblewski. Dąbrowa Górnicza: Wydawnictwo Naukowe Wyższej Szkoły Biznesu w Dąbrowie Górniczej.

11. Kurowska-Pysz, Joanna, Wróblewski Łukasz, and Szczepańska-Woszczyna Katarzyna. 2017. Identification and assessment of barriers to the development of cross-border cooperation. In Innovation Management and Education Excellence through Vision 2020. Edited by Khalid Soliman. Milano: Proceedings of the 31st International Business Information Management Association Conference. ISBN: 978-0-9998551-0-2

12. Kurowska-Pysz, Joanna. 2016. Opportunities for Cross-Border Entrepreneurship Development in a Cluster Model Exemplified by the Polish-Czech Border Region. Sustainability 8, 230. DOI:10.3390/su8030230

13. Mynarski, Stefan. 1973. Cybernetyczne aspekty analizy rynku. Warsaw: Wydawnictwo Naukowe PWN.

14. Mynarski, Stefan. 2000. Analiza rynku. Makromechanizmy. Cracow: Wydawnictwo Akademii Ekonomicznej w Krakowie.

15. Rusek, Halina, Kasperek Andrzej. 2012. Sympatie i antypatie polsko-czeskie w świetle badań nad antagonizmem i pojednaniem polsko-czeskim na Śląsku Cieszyńskim. In: Pogranicze-SąsiedztwoStereotypy. Przypadek polsko-czeskich relacji wraz z francusko-niemieckim case study. Edited by Andrzej Kasperek. Cieszyn-Katowice: Polska Akademia Nauk Oddział w Katowicach-Stowarzyszenie Rozwoju i Współpracy Regionalnej „Olza”. ISBN 978-83-89796-66-0

16. Sobocińska, Magdalena. 2008. Zachowania nabywców na rynku dóbr i ustug kultury. Warsaw: PWE. ISBN 978-83-208-1753-9

17. Szomburg, Jan. 2002. Kultura i przemysły kultury szansą rozwojową dla Polski. In: Kultura i przemysty kultury szansa rozwojowa dla Polski. Edited by Jan Szomburg. Gdańsk: Instytut Badań nad Gospodarką Rynkową, Gdańsk.

18. Werpachowski, Lesław. 2014. Regionalna współpraca transgraniczna na Śląsku Cieszyńskim. Doświadczenia i perspektywy. In: Euroregion Śląsk Cieszyński - Těšínské Slezsko. Wspótpraca transgraniczna i międzyregionalna prowadzona w obszarze trójstyku polsko-czesko-stowackiego. Edited by 
Andrzej Kasperek, Cieszyn-Katowice: Polska Akademia Nauk Oddział w KatowicachStowarzyszenie Rozwoju i Współpracy Regionalnej „Olza”. ISBN 978-83-60071-77-9

19. Wróblewski, Łukasz. 2014a. Wpływ kultury i przemysłów kultury na wizerunek Euroregionu Śląsk Cieszyński. In: Euroregion Śląsk Cieszyński - Těšínské Slezsko. Wspótpraca transgraniczna i międzyregionalna prowadzona w obszarze trójstyku polsko-czesko-słowackiego. Edited by Andrzej Kasperek, CieszynKatowice: Polska Akademia Nauk Oddział w Katowicach-Stowarzyszenie Rozwoju i Współpracy Regionalnej „Olza”. ISBN 978-83-60071-77-9

20. Wróblewski, Łukasz. 2014b. The Influence of Creative Industries on the Socioeconomic Development of Regions in Poland. International Journal of Entrepreneurial Knowledge 2: 45-57.

21. Wróblewski, Łukasz. 2015. Websites of Polish cultural and educational organizations in the Czech Republic-Analysis and evaluation. Forum Scientiae Oeconomia 3: 65-78.

22. Wróblewski, Łukasz. 2016. Marketing strategiczny w sektorze kultury Euroregionu Ślask Cieszyński. Warsaw: CeDeWu. ISBN 978-83-7556-845-5.

23. Wróblewski , Łukasz. 2017b. Application of marketing in cultural organizations: the case of the Polish Cultural and Educational Union in the Czech Republic. Cultural Management Science and Education 1: 79-92.

24. Wróblewski, Łukasz. 2017a. Cultural Management. Strategy and Marketing Aspects. Berlin: Logos Verlag Berlin. ISBN 978-3-8325-4378-5.

25. Wróblewski, Łukasz, Kurowska-Pysz Joanna, and Zdzisława Dacko-Pkiewicz. 2018b. Polish-Czech micro-projects as a tool for shaping consumer behaviour on the cross-border market for cultural services. In: Innovation Management and Education Excellence through Vision 2020. Edited by Khalid Soliman. Milano: Proceedings of the 31st International Business Information Management Association Conference. ISBN: 978-0-9998551-0-2

26. Wróblewski, Łukasz, Dziadzia Bogusław, and Zdzisłąwa Dacko-Pikiewicz. 2018a. Sustainable Management of the Offer of Cultural Institutions in the Cross-Border Market for Cultural ServicesBarriers and Conditions. Sustainability 10, 9. DOI:10.3390/su10093253. 